\title{
高分子の表面分析 一実用材料の表面・界面分析一
}

Surface Analysis of Polymer

薄木智亮 集友金属テクノロジー(株) 渡邊緩子 集友金属テクノロジー(株)

高分子材料は，バルクとしての特性のほか，濡れ性などの表面物性や他材料との密着性な どの界面物性が要求される. 本稿では, 塗装鋼板などの実用材料を対象に, 表面分析で得 られた表面・界面の状態と物性と，最近の分析動向について紹介する.

\section{1.はじめに}

高分子材料の表面分析は, 1970 年代に X 線光電子分 光法 (XPS; X-ray Photoelectron Spectroscopy) が, 汎 用されるようになると同時に，さかんに行われてきた。 このXPS は，特性 X 線を試料表面に照射し，放出され た光電子の運動エネルギーを測定することによって，表 面の数ナノメートル深さの元素の結合状態や組成を知る ことができる方法である，同時期に市販され，汎用的と なった表面分析法であるオージェ電子分光法 (AES; Auger Electron Spectroscopy) では得られない, 高分 子材料にとって重要な表面元素の化学状態の情報が得ら れるほかに，絶縁体でも分析が可能なことや分析時の高 分子の損傷が少ないことなどの利点を有している.

また，従来加有機物の分子構造解析に用いられてき たフーリ工変換赤外分光法 (FT-IR; Fourier Transform Infrared Spectroscopy) む, 拡散反射法や全反射法が活 用されるようになり高分子材料の表面分析法として大き な寄与をしてきている。

さらに最近では, 表面第 1 層の化学的な構造の情報が 得られる飛行時間型—次 1ォン質量分析法 (TOF-SIMS; Time of Flight Secondary Ion Mass Spectroscopy) が 開発され，市販されてきている，これは，XPSに比べ検 出感度, 空間分解能が優れるとともに, 絶縁物の分析む 可能となっており, 高分子表面の分析への適用が著しく 増大してきている.

本稿では，これらの分析手法を(1) 多成分系高分子材 料の表面・界面偏析，(2) 金属 - 酸化物／接着界面反応 について，特に実用的な材料を対象として適用した例を 述べる.

\section{2. 高分子材料の表面・界面偏析}

XPS は, 高分子材料の表面組成を分析することので
きる優れた方法の一つであり, 単に元素の組成が求まる だけでなく, 炭素 $1 \mathrm{~s}$ をはしめ, 室素, 酸素, フッ素など の $1 \mathrm{~s}$ 光電子ピークに現れるケミカルシフトを利用し, 高分子の成分濃度が解析できる，この特徴を活用して, 多成分系高分子材料の表面や異種材料との接着界面にお ける, 特定成分の表面偏析や界面偏析がさまざまな系で 研究されてきた.

高分子材料の表面（ここでは，空気一固体界面）は, 表 面自由エネルギーの小さい成分が濃化することが知られ ている ${ }^{1) 33}$.

一方, 表面偏析と界面偏析の関係については, 報告例

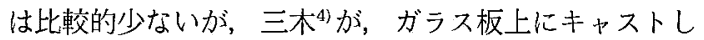
た含フッ素ポリマーと非含フッ素ポリマー混合膜で調査 して抢り，大気側表面では，含フッ素ポリマーが，ガラ ス側界面では, 非含フッ素ポリマーが濃化することを示 している. 界面偏析の報告例が少ないのは, 界面を表面 分析用試料とするための試料作成がやや困難なためとい えよう.

ところで，川西らが，実用的な塗装鋼板に使用され ているポリエステルーメラミン系塗膜の表面偏析と界面 偏析の関係を, 表面自由エネルギーの異なったメラミン 種を用いた電気亜鉛めっき上の塗膜系で検討している. 塗膜の表面と界面 (塗膜側) をXPS で測定したメラミ ン濃度と，ポリエステルに対するメラミン種の表面自由 エネルギー比の関係を図 1 に示す。このメラミン濃度 は,メラミン単体塗膜に扔いてXPS で検出された室素 濃度に対するポリエステルーメラミン系塗膜のXPSに 上る窒素濃度の比として求められている。図中 $\theta$ は, 試 料表面に対する光電子の取り出し角で，小さい方がより 表面の情報が得られる.なお界面は, 塗膜試料を接着し， 液体窒素に冷却後剝離させ，出現させた，表面では，表 面自由エネルギー比が小さいほどメラミンが濃化した。 界面側では, 表面自由エネルギー比が大きいほどメラミ 


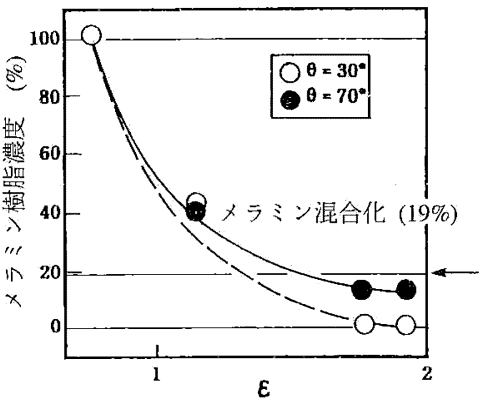

(a) 塗膜表面

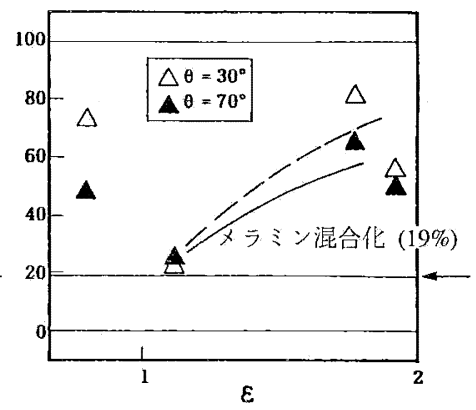

(b) 塗膜界面

図 1 メラミンとポリエステルの表面自由エネルギー比 $(\varepsilon)$ と表面・界面 におけるメラミン濃度ら

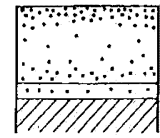

PB

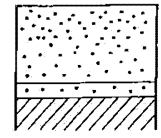

PMX

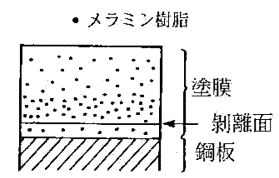

PML, PI
図 2 塗装鋼板の塗膜の組成模式図 ${ }^{5)}$ $\mathrm{PB}:$ ポリエステル/ブチル化メラミン系塗膜, PMX: ポリ エステルメチル化メラミン系㳂膜, PML: ポリエステ ル/メチロール基型メラミン系塗膜, PI: ポリエステル／ イミノ基型メラミン系塗膜

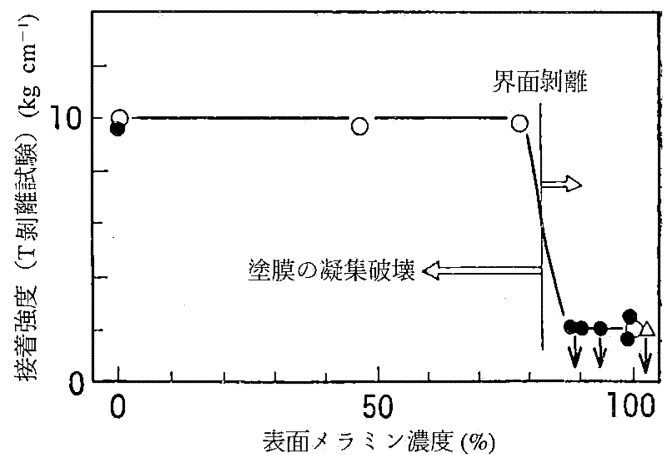

図 3 ポリエステル/メラミン綮塗膜の表面メラミ ン濃度と接着性の関係 ${ }^{8)}$

ンが濃化する傾向があったが，相溶性の悪い場合は，表 面自由エネルギー比が小さいときです，濃化が認められ た. 一方，電気亜鉛めっき鋼板上に屯樹脂が数ナノメ一 トル厚さで残存しており, 塗膜のバルク組成とほぼ一致 した。これらの結果は, 表面では, 表面自由エネルギー が小さくなるような殏脂組成になり，界面では，鋼板表 面の樹脂が数ナノメートル厚さの吸着層を除いて, 基本 的には，表面自由エネルギーが大きくなるような樹脂組 成になるが，相溶性が悪い場合は，表面自由エネルギー にかかわらず，表面，界面ともに濃化することを示唆し ている. また，界面鋼板側の樹脂吸着層は，塗膜の塗付 時に形成され，焼付時にも残存したと考えられた，図2
に塗膜表面および界面の模式図を示 के.

このように高分子の表面・界面の 組成を分析するために XPS は，非 常に有力な手段である.さらに最近 では，表面 1 分子層の情報を得るた めに, TOF-SIMSが利用されてい る. Jeadley $ら^{6)}$ は，溶融带鉛めっ き鋼板上のエポキシ樹脂表面を，高 分解能 XPS と TOF-SIMS で分析 し，微量成分であるメチル化メラミ ンが濃化していることを見いだし た，高分解能XPS ではそのほか, アクリル樹脂の濃化も確認されているが，TOF-SIMS では，検出されなかった。このことは，メラミンは，表 面 1 分子層にむ濃化しているが, アクリル樹脂は，表面

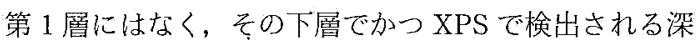
さ数ナノメートル程度で濃化していることを示唆してお り，TOF-SIMS とXPS を併用することで表面偏析の層 構造が明らかにされると期待できる.

また, 表面偏析に関しては, 高原ら7〕, ポリスチレン を一成分としたメトキシ(ポリエチレングリコール)メ夕 クリレートなどとのジブロック共重合体を用いて検討し ている. この結果, 空気一固体界面では, 低自由エネル ギー成分が表面に濃化するが，水中へ移行させることに よって, 表面は, 親水性に富むようになることを示した。 すなわち，高分子材料は，室温において，表面が接する 環境により，表面状態が变化する.

実用材料においては，上述のような表面偏析や界面偏 析が，濡れ性や接着性などの表面物性や密着性などの界 面物性に大きな影響を及ぼすことが知られてきている.

壱岐島ら ${ }^{8)}$ は，家電分野に使用されている塗装鋼板の ポリエステルーブチル化メラミン架橋塗膜表面の組成変 化と濡れ性や接着性，耐マジック污染性の相関について 調査している，その結果，メラミンが，ポリエステル塗 膜表面に濃化し，水に対する濡れ性や図 3 に示すような ウレタン系接着剤との接着性は, ポリエステル種に依存 せず，XPS で測定されるようなごく表面のメラミン濃 度に依存することを報告した。これらの結果は，表面偏 析や界面偏析を積極的に利用，あるいは，阻止した材料 の設計にお扑に役立っている。

\section{3. 金属・酸化物／高分子界面の反応}

高分子材料は，接着接合においても重要な位置をしめ ている. 接着反応は，高分子上金属・半導体・(水) 酸化 物の界面での酸塩基相互作用に基づくといわれてきてお り, 接着界面の反応屯, 表面分析技術で解明されつつある. 
(1) PAA 薄 膜
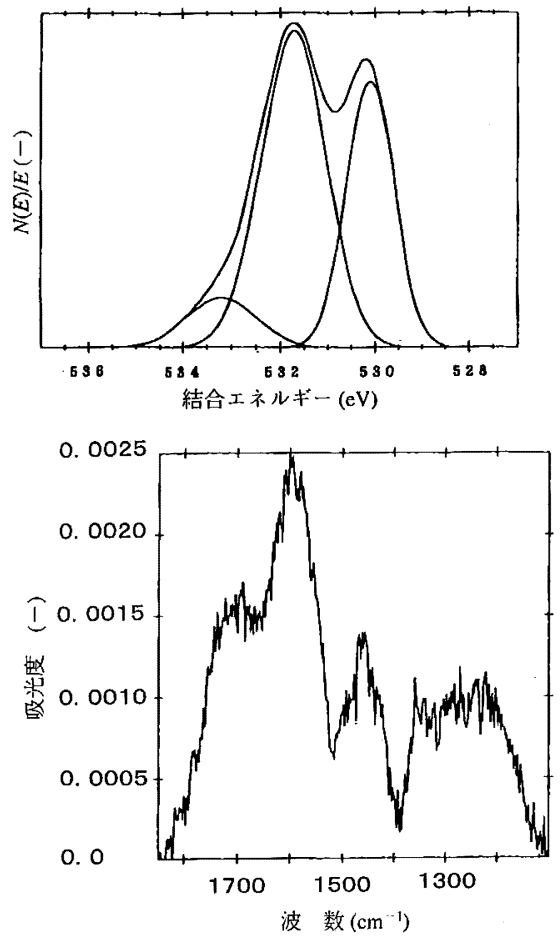

(2) PMAA 薄膜
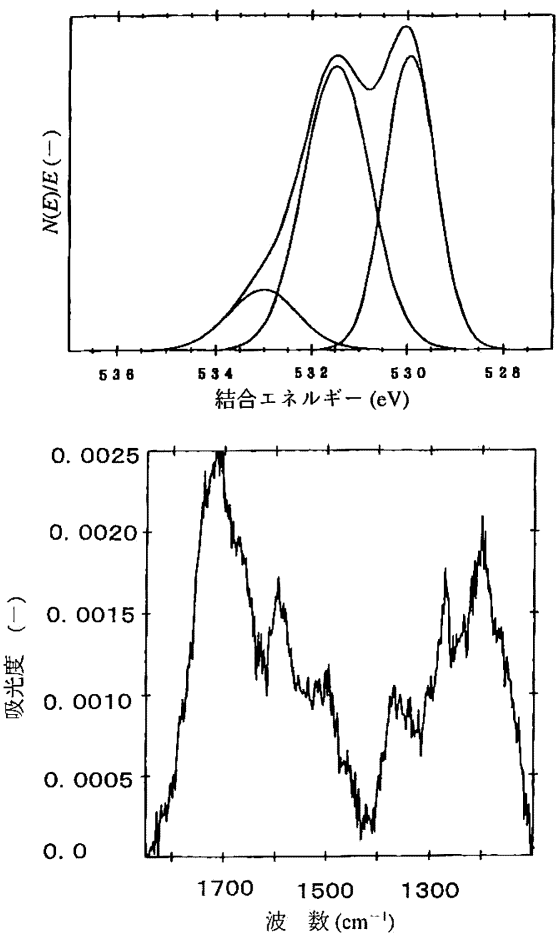

図 4 ステンレス上の PAA, PMAA 薄膜の XPS, 全反射 FT-IR スペクトル

接着界面を表面分析装置を用いて分析するためには, 高分子の情報と金属などの基板の情報が，同時に測定さ れなければならない，例えば，XPS を用いる場合は，検 出深さ数ナノメートル以内の厚さに, 高分子と基板が存 在するようにしなければならない.

このためには，第 2 節の界面偏析で述べたように，高 分子と基板の界面で剥離させる方法が従来から用いられ てきた. しかしながら，接着強度が強い試料においては， 界面剝離を現出させることが非常に困難である.

そこで, 最近では, 分析装置の高真空中で高分子基板 上に金属を薄く蒸着して状態変化を観察する方法や，大 気中あるいは不活性雾囲気中で金属, 酸化物などの基板 を高分子希薄溶液に浸漬し，高分子薄膜を形成させる方 法なごが試みられてきた。

ここでは，上述の方法のそれぞれを紹介する.

基板と高分子を剝離する方法では, 谷山ら9 が表面状 態を変化させたアルミニウム基板と軟質ゴム系接着剤と の界面をXPS で観察している. 水酸化物と酸化物が存 在するアルミニウム表面で, 水酸化物 $(\mathrm{Al}-\mathrm{OH})$ が多い場 合，凝集破壊を生じ接着性が良好であったが，酸化物 (Al-O) が多い場合, 界面剝離を生じた. 前者では, 界面 に塩化ビニルが, 後者ではアミンが濃化しており,アミン の濃化が，接着性の劣化をむたらしたと結論している.
アミンが塩基性であるため, 塩基性の $\mathrm{Al}$ 水酸化物表面 より両性の Al 酸化物表面に濃化したと考えている.

高分子に金属を蒸着する方法では，LSI などの層間絶 縁膜として広く用いられているポリイミドと種々の金属 の相互作用が数多く調べられている。これらはいずれ

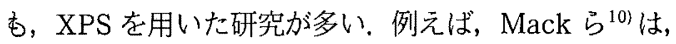

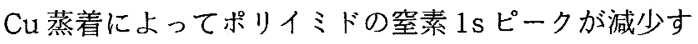
ることから, pyromellic dianhydride (PMDA) のイミ ド基と相互作用すると結論している，この方法は，しか しながら，分析装置に蒸着源が付属している必要がある ため，一般的には用いることが困難である.

一方，金属や酸化物基板を高分子希薄溶液に浸漬し高 分子薄膜を形成させる方法では, 界面における高分子の 結合状態を基板間で比較，あるいは，薄膜と厚膜との比 較を通して反応状態を予測している.

Kelber ら"11 は, ジェタノールアミン (DEA)のエタ ノール溶液を用いて DEA と酸化銅, 酸化アルミニウム, リン酸で陽極酸化させたアルミニウムの界面反応を XPS で解析し, 窒素 1 ピ ピークのケミカルシフトから, アミンの $\mathrm{N}$ 原子の孤立電子対が酸化アルミニウムおよ びリン酸塩処理したアルミニウム表面に配位しているこ とを示した。

また, 谷山ら ${ }^{12)}$ は, $\mathrm{MgO}, \mathrm{Al}_{2} \mathrm{O}_{3}, \mathrm{SiO}_{2}$ の表面清浄化し 
た酸化物基板上にエポキシ樹脂のトルエン溶液を用いて エポキシ樹脂膜を形成させ，XPSを用いて，相互作用を 調査している.この結果, $\mathrm{MgO}$ 基板上にのみエポキシ 基か配向し，炭素 $1 \mathrm{~s}$ の $\mathrm{C}-\mathrm{O}$ ピークにシフトが認められ たことから， $\mathrm{MgO}$ からエポキシ基に電子を供与するよ うな相互作用が生じていることを考察した。

近年では，XPS のほかに FT-IR, TOF-SIMS を利用 した界面反応の研究むなされてきている. 山辺ら ${ }^{13)}$ は, ステンレス鋼に接着耐久性を付与するために，ポリアク リル酸 (PAA) とポリメタクリル酸 (PMAA) 薄膜処理の 検討を行い, PAA 処理に効果を認めた.この原因につい て, 彼らはXPS, FT-IR, TOF-SIMS で調查した。なお, 薄膜処理は, ステンレス鋼を酸洗, 水洗後, PAA あるい はPMAA 水溶液に浸漬し作成している.

XPS では，図 4 上に示すように, PAA ではPMAA に比べて, $531.4 \mathrm{eV}$ のルボン酸アニオンのピークが $533.3 \mathrm{eV}$ のカルボン酸二量体のピークより大きい. カ ルボン酸アニオンはステンレス表面とカルボキシル基と の間で，電子移動を伴う相互作用の結果生じることか ら, PAA との相互作用が強いと指摘している. さらに, 図 4 下に示すように, 反射吸収 FT-IR でも, PAA の方 が PMAA より $1600 \mathrm{~cm}^{-1}, 1450 \mathrm{~cm}^{-1}$ 付近のカルボン 酸アニオンの伸縮振動の吸収が強いことを確認してお り, XPSの結果と一致している. TOF-SIMS では, PAA 処理で PMAA 処理より $\mathrm{Fe}^{+}, \mathrm{Ni}^{+}, \mathrm{Cu}^{+}$イオン強度 が強く出ていることから, ステンレス表面との相互作用 が強いことが示唆されている。

これらの結果より, PAA 処理で接着耐久性が優れた 理由は, カルボオキシル基とステンレス表面でカルボン 酸アニオンを形成するような電子の授受を伴う強い相互 作用をあつためと結論している.

以上述べたように，高分子と金属・酸化物などとの相 互作用の研究は, 抒もにXPSを用いて, 組成の変化, 結 合状態の変化を分析する方法で進められてきた. 今後 は, XPS とともに FT-IR, TOF-SIMS を組み合わせ, より精度の高い分析がなされると期待できる.

\section{4.おわりに}

本稿では, 高分子材料の中で，実用的な材料の基本的 な問題解決のための表面分析例を紹介した. 高分子の表 面・界面状態は, 表面・界面物性に大きな影響を与える ことから, 数多くの研究がなされてきている. 本稿で紹 介できなかった，プラズマ処理や紫外線照射などの表面 改質などあ表面分析の大きな対象である.

分析手法としては，XPSが最も多く用いられてきた. XPS では, 従来ミリメートルオーダーの空間分解能で あったが, 最近では, 数十マイクロメートルオーダーの 高分子 48 巻 9 月号（1999 年）
分析も可能となってきている. 今後は, TOF-SIMS む, 表面第 1 層の分析手段として, また, マイクロメートル オーダーの微小部分析の手段として, おおいに活用され ると考えられる. 一方, FT-IR も顕微全反射 FT-IR 法 により, 空間分解能として $10 \mu \mathrm{m}$ の表面分析む可能と なってきている.

このように，高分子材料の表面分析も微小部を対象之 することができるようになり，今後ますます適用範囲が 広がると考えられる.

しかしながら，高分子材料は，本稿で述べたように， 室温であ環境の変化によって表面構造を変化させたり, 分析時の X 線や電子，イオンの照射により化学構造を 変化させることが知られており，デー夕解釈には十分な 注意が必要である. さらに, 界面の相互作用の解析には, 試料作成の工夫が大きなポイントとなり，今後，目的に あった試料作成法の開発と分析法の組合せを考案してい くことが必要となってくると考えられる.

\section{文献}

1) D. Pan, W. M. Prest, Jr.: J. Appl. Phys., 5, 2861 (1985)

2）加納義久, 石倉一仁, 秋山三郎：日本接着学会誌， 26,252 (1990)

3) 多留康矩, 高岡 京: 高分子論文集, 44, 9 (1987)

4) 三木哲郎：化学と工業, 42, 837 (1989)

5) 川西勝次，薄木智亮：日本接着学会誌，30, 258 (1994)

6) S. L. Leadley, J. F. Watts, C. J. Blomfield, C. Lowe: Surf. Interface Anal., 26, 444 (1998)

7) 高原 淳, 寺屋竜男, 梶山千里：高分子論文集, 47,395 (1990)

8) 壱岐島健司, 薄木智亮, 須藤妙子, 八内昭博, 塩田俊明: 色 材, 64, 780 (1991)

9) 谷山 明, 薄木智亮, 福井清之, 大栗靖弘: 材料とプロセス, 8, 1626 (1995)

10) R. G. Mack, E. Grossman, W. N. Unertl: J. Vac. Sci. Technol., A8, 3827 (1990)

11) J. A. Kelber, R. K. Brow: Appl. Surf. Sci., 59, 273 (1992)

12) 谷山 明, 薄木智亮: 表面科学, 42,320 (1995)

13）山辺㶪敏, 天野晋武, 藤原俊明, 加連明也：色材, 69,158 (1996)

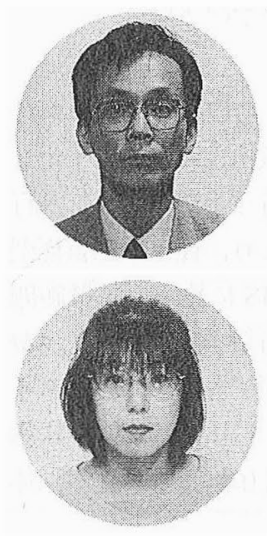

薄木智亮 住友金属テクノロジー(株) （660-0891 尼崎市扶桑町 1-8）次長, 工博

1974 年大阪大学理学部化学科卒, 同 年住友金属工業(株)入社, 1998 年よ り現職に出向. 専門は表面分析.〈趣 味〉能楽鑑賞

渡傻緩子 同上・主事, 薬学修士 1990 年神戸薬科大学薬学部薬学科 卒, 1992 年同大大学院薬化学研究科 修士課程修了, 同年より現職. 専門は 有機分析.〈趣味〉料理 